\title{
THE EFFECTIVENESS OF HEALTH EDUCATION OF BREASFEEDING PREPARATION ON PRIMIGRAVIDA MOTHER'S MOTIVATION TO PROVIDE EXCLUSIVATION
}

\author{
Ika Agustina \\ Midwifery Department, Patria Husada Blitar School of Health Science \\ email:ikapatria45@gmail.com
}

\begin{abstract}
Exclusive breastfeeding is the pure one without additional fluids, either formula, water orange juice or other supplementary foods before reaching the age of six month. Giving breasfeeding is very benefical for baby, mother, family, and country. The purpose of this study was to analyze the effect of health education on breasfeeding preparation of mother's motivation to provide exclusive breasfeeding. The type of the study used pre-experimental design. The populastion used in this study was 15 primigravida mother's. The sample was 15 respondents taken by Consecutive sampling technique. The instrumen used questionnaire sheet. The statistical test used Paired Sample t Test. The results showed that the motivation of mother primigravida after being given health education become strong motivation equal to $40 \%$. The resulth of analysis using Paired Sample t Test Test showed the value of $p$ value $=0,000$, so $p$ value $=0,000<0,05$ or significant, it meant that there was an effect of health education of breasfeeding preparation to motivate primigravida mothers to give exclusive breasfeeding. Based on the results of the study is expected to primigravida mothers's to improve health education in the preparation of breasfeeding and to health workers further increase the primigravida mother's mitigation to provide exclusive ation to achieve exclusive ation success.
\end{abstract}

Keywords: Motivation, Exclusive Breastfeeding, Benefits

\section{INTRODUCTION}

Lactation is the whole process of breastfeeding from breast milk is produced through the process of the baby sucking and swallowing milk. Lactation period has the purpose of improving exclusive breastfeeding and continue breastfeeding until 2 years old children properly and correctly and children get natural immunity (Wiji, 2013).

Exclusive breastfeeding is breastfeeding without food or drink companion (including water, honey, sugar water), which began in newborns up to the age of 6 months (Sulistyawati, 2009). While breast milk is not the same as the formula one of them that colostrum is a viscous liquid with a yellowish color that contain more protein and can provide protection for up to 6 months, and the factor of bifidus that promote the growth of good bacteria in the intestines of infants against growth of pathogenic bacteria so the risk of experiencing diarrhea is lower.

Primigravida are women who are pregnant for the first time. This period of pregnancy starts from conception until the birth of the fetus. Primigravida's mother was a woman who first became pregnant. Furthermore, pregnancy occurs when there is a meeting between the egg (ovum) and semen (spermatozoa) (Prawirohardjo, 2009).

Breastfeeding problems to the mother one of them because the channel of milk is clogged, human milk glands have $15-20$ breast milk channels. One or more of these channels can be blocked due to finger pressure while breast-feeding mother, the baby or bra that is too tight, so most do not drain the milk ducts. Blockages can also occur because of the milk in the channel is not immediately released because there is swelling (Wiji, 2013). 
Due to lack of information, many mothers who consider formula milk as good, even better than breast milk. This causes mothers to give formula milk faster if they feel less milk. In addition, the mother is also less aware of how to breastfeed effectively and what are the benefits that can be obtained by the mother if the mother gives exclusive breastfeeding to her baby (Wiji, 2013).

Preparation breastfeeding conducted simultaneously with the pregnancy, the breasts more dense because of the retention of fat, and the development of breast glands felt tense and sore. Immediately after pregnancy occurs, the corpus luteum continues to grow and secrete estrogen and progesterone to prepare the breast so that in time can give milk (Sitti, 2009).

According to Riskesdas 2013, the process of starting breastfeeding most occurred at 1-6 hours after delivery (35.2\%) and less than 1 hour by $34.5 \%$. While the lowest breastfeeding process occurs at 7-23 hours after birth is $3.7 \%$. Referring to the 2014 strategic plan target of $39 \%$, the nationwide coverage of exclusive breastfeeding for infants aged less than six months was $55.7 \%$. According to East Java province, the range of process category coverage started breastfeeding in infants $<1$ hour (IMD) $33.3 \%$, breastfeeding category 1-6 hours $33.5 \%, 7-23$ hours $3.3 \%, 24-47$ hours $15.3 \%$, and > 48 hours $14.7 \%$. While data obtained from the central statistical agency (BPS) Blitar district in 2016 as many as $40 \%$ of mothers who failed to provide Exclusive breastfeeding due to breast milk has not come out, nipple drown so that mothers can not prepare to provide Exclusive Breast Milk.

As a result of not exclusive breastfeeding so that the composition obtained is not in accordance with the needs of infants so that protective / antibody protective against disease has a risk 17 times higher for diarrhea and three to four times more likely to get respiratory infection compared with breastfed babies.

With the existence of these problems, the authors are interested in conducting a study entitled "Effect of health education about breastfeeding preparation against primigravida motivation to give exclusive breastfeeding"

\section{METHOD}

The design used in this study was preexperimental design with pretest-posttest design approach.
The population in this study were 15 Primigravida Trimester III pregnant women at Sri Sulikah private midwifery practionary in Gogodeso village Kanigoro sub-district, Blitar regency. Samples taken from this research are pregnant women primigravida Trimester III In Sri Sulikah private midwifery practionary in Gogodeso village, Kanigoro District Blitar who has the criteria of inclusion and exclusion. Sampling in this study using non probability sampling that is consecutive sampling.

The instruments used are checklist with the model strongly agree, agree, disagree, strongly disagree. Chek list or checklist in the form of a list that contains lists and questions to be observed and respondents provide answers by providing answers chek (") in accordance with the results of observation.

Analysis of the influence of health education of breastfeeding preparation on mother primigravida motivation to give exclusive breastfeeding after the data obtained is processed and tabulated then the data of motivation before and after health education is analyzed using paired sample $t$ test that is parametik test used in hypothesis testing with two paired samples.

\section{RESULT}

\section{Responden Characteristic}

The research was conducted in Gogodeso Village, Kanigoro District, Blitar District. Characteristics of respondents in this study include age, education, employment and information.

The results showed that most $(66.7 \%)$ of primigravida mothers aged 20-30 years, most $(53.3 \%)$ of primigravida mothers with junior high school education, most $(73.3 \%)$ of primigravid mothers were housewives, and most $(53.3 \%)$ of primigravid mothers ever received information about breastfeeding preparations.

Table 1 Distribution of primigravid mother motivational frequencies in exclusive breastfeeding prior to health education

\begin{tabular}{llcc}
\hline No & Motivation & f & \% \\
\hline 1 & strong & 0 & 0 \\
2 & midle & 6 & 40 \\
3 & weak & 9 & 60 \\
\hline & Totally & $\mathbf{1 5}$ & $\mathbf{1 0 0}$ \\
\hline
\end{tabular}


Motivation of mother primigavida in giving exclusive breastfeeding before given health education

Based on Table 1 shows most (60\%) primigavida mothers have a weak motivation in giving exclusive breastfeeding before being given health education.

Primigavida maternal motivation in providing exclusive Breastfeeding after being given health education

Table 2 Distribution of primigravid mother motivational frequencies in exclusive breastfeeding after health education

\begin{tabular}{llcc}
\hline No & Motivation & f & \% \\
\hline 1 & strong & 10 & 66,7 \\
2 & midle & 5 & 33,3 \\
3 & weak & 0 & 0 \\
\hline & Totally & $\mathbf{1 5}$ & $\mathbf{1 0 0}$ \\
\hline
\end{tabular}

Based on Table 2 shows most $(66.7 \%)$ primigravida mothers have a strong motivation in giving exclusive breastfeeding after being given health education.

Effect of health education about breastfeeding preparation on the motivation primigravida in exclusive breastfeeding

The results showed an increase in the percentage of motivation primigravida to the preparation of breastfeeding before and after administration of health education is of motivation is becoming a strong motivation for $40 \%$. Statistical test paired sample $t$ test was obtained $p$ value $=$ 0.000 , so the $p$ value $=0.000<a ́=0.05$, indicating the influence of breastfeeding on the health education preparation primigravida motivation for exclusive breastfeeding in the Gogodeso village Kanigoro District of Blitar.

\section{DISCUSSION}

Motivation of mother primigavida in giving exclusive breastfeeding before given health education

Based on table 1 shows most $(60 \%)$ primigavida mothers have a weak motivation in giving exclusive breastfeeding before being given health education. Motivation is an impulse arising from the stimulation of the inside and outside of self so that someone wants to make a change of behavior or certain activities better than the previous situation (Hamzah, 2011).

Based on the results of research conducted on 24 June 2017 in Polindes Gogodeso Kanigoro District Blitar district on the respondents who have not provided health education for breastfeeding preparation of primigravida mother's motivation to provide Exclusive breastfeeding is known mostly 9 respondents $(60 \%)$ primigravida mothers are included in the category of weak motivation because poor mother's knowledge of breastfeeding preparations so that the preparation of primigravida mother's breastfeeding for exclusive breastfeeding is not strong yet.

The results showed most $(66.7 \%)$ primigravida mothers aged 20-30 years and all were primigravida mothers. Education is important because as the higher level of education, the openness and awareness of the acceptance of information will be different from the lower level of education. Based on the general tabulation of data we can know that the level of education of primigravida mothers is low tend to have weak motivation because of weak mother's knowledge to prepare breastfeeding before given health education preparation of breastfeeding to motivation of mother primigravida to give exclusive breastfeeding.

The results showed most (73.3\%) primigravida mother is housewife. Primigravida mothers who do not work or at home usually will be busy with the work of home care. Based on general tabulation data we can see that primigravida mothers have a moderate motivation to make breastfeeding preparations before being given a health education. However, as many as 8 respondents (53.3\%) never received information about breastfeeding preparation for primigravida mother's motivation to give exclusive breastfeeding. The lack of motivation of primigravid mothers who do not work for breastfeeding preparation is due to the lack of information resources acquired, making it difficult to alter the assumptions they believe so far.

\section{Primigavida maternal motivation in exclusive breastfeeding after being given health educa- tion}

Based on the results of the research on the respondents after given health education it is known that most $(66,7 \%)$ as many as 10 respondents primigavida mothers have strong motivation in giving 
exclusive breastfeeding after given health education while $(33,3 \%)$ as many as 5 respondents primigravida mother have medium motivation. Respondents did not make preparations for breastfeeding because prepregnant breastfeeding health education for primigravida mothers to provide exclusive breastfeeding is still low, so the motivation of primigravida mother in preparing breastfeeding to provide exclusive breastfeeding before and after being given health education changes.

Health education becomes an intrinsic factor that a person possesses because information can give someone a push to do something. Health education is a form of intervention or effort directed to behavior, so that the behavior is conducive to health (Notoadmodjo,2010). The increased health of respondents will be able to understand the preparation of breastfeeding so that primigravida mothers have a strong motivation and can provide exclusive breast milk well and correctly.

This study are given health education on the effect of health education on the motivation primigravida for exclusive breastfeeding in the form of a presentation and asked questions about matters concerning the preparation of breastfeeding to primigravida. With an effective lecture and questionand-answer methodology in the delivery and delivery of breastfeeding preparation and raising the motivation of primigravid mother to provide Exclusive Breast Milk.

No respondents have weak motivation after being given health education. The tendency of acceptance and understanding of the information provided by the researchers on the preparation of breastfeeding on maternal motivation primigravid for exclusive breastfeeding in a language that requires more penalatan will have an impact on the motivation of respondents. Motivation is an impulse arising from the stimuli from within the self and from outside the self so that someone wants to make a change of behavior or a certain activity better than the previous situation. One's tendency to act depends on the power of motivation and attraction of the self within oneself.

\section{Effect of health education about breastfeeding preparation on the motivation primigravida in exclusive breastfeeding}

Based on the results of the study showed that the increase of the percentage of primigravida mother motivation to the preparation of breastfeeding before and after being given health education that is from moderate motivation become strong motivation by $40 \%$. Based on statistical test of pairet sample $t$ test obtained $p$ value $=0,000$ so $p$ value $=0,000<\alpha=0,05$ which means showing influence of health education of breastfeeding preparation toward motivation of mother of primigravida to give exclusive breastfeeding in Gogodeso Village Kanigoro sub-district, Blitar regency. The results indicate that health education is one of the motivating factors of primigravida mother in giving exclusive breastfeeding through good and correct breastfeeding preparation.

Based on the research results we can know that the influence of health education is very diverse, the difference is caused by the differences in age, education level, and work. Because the older age, the lower the curiosity, the influence is also greater. Similarly with the level of education, the higher the level of information receiving education the better. The low motivation of primigravida mother in Polindes of Gogodeso Village, Kanigoro Sub-district, Blitar Regency is caused by the lack of public knowledge about the importance of giving Exclusive Breast Milk, proved in the research result that $53.3 \%$ of primigravida mothers never got information about Exclusive Breast Milk.

Changes can happen to every individual as a result of influence, in this research the influence given is health education. Health education is an attempt to influence or invite others, whether individuals, groups or communities. Health education is in fact a dynamically changing process of development, in which a person accepts or rejects information aimed at a healthy life.

The end result of this counseling is the motivation of primigravida mothers to give exclusive breastfeeding increases, so they are not afraid to make breastfeeding preparations. In this study most of the motivations of primigravida mothers experienced a change in improvement, and no decrease from before and after given health education.

From the results of the study we can see that there are still primigravida mothers who have moderate motivation $33.3 \%$ as many as 5 respondents. Where after given health education all motivation of mother of primigravida can increase without exception, this is because education level, low level of education will make the individual more difficult to receive information to make change, 
besides that factor there are other factors that have an important influence to the increase of motivation that is activeness and ask at a time when health education is taking place, because by actively asking primigravida mothers can get answers or solutions of problems that make them not give Exclusive Breast Milk. Activity itself can be influenced by the desire that cause curiosity, that is the cause of the existence of primigravida mothers who have moderate motivation in this study.

\section{CONCLUSION AND SUGGESTION}

\section{Conclusion}

Based on the results of research conducted it can be concluded as follows: The motivation of the primigravida mother before being given a health education gave exclusive breastfeeding in the weak category of $60 \%$ (9 primigravida mothers), Motivation of primigravida mother after being given health education gave exclusive breastfeeding in the strong category of $66.7 \%$ (10 primigravida mothers), There is an influence of health education on breastfeeding preparation of primigravida mother's motivation to provide exclusive breastfeeding with $\mathrm{p}$ value $=0,000$.

\section{Suggestion}

Expected to use material about lactation management as one of the material in counseling to patient or in a learning activity on midwifery

It is expected that in the class of pregnant women can improve the health education of breastfeeding preparation, especially to primigravida mothers in order to achieve exclusive ASI success.

\section{REFERENCES}

Hamzah B. 2011. Teori Motivasi dan Pengukurannya. Jakarta: Bumi Aksara

Notoadmodjo, soekidjo.2010. Kesehatan Masyarakat. Jakarta: Rineka Cipta

Prawirohardjo.2009.Ilmu Kebidanan. Jakarta: Bina Pustaka.

Sitti, Saleha. 2009. Asuhan Kebidanan Pada Masa Nifas. Jakarta: Salemba Medika

Sulistyawati, Ari. 2009. Buku Ajar Asuhan Kebidanan pada Ibu Nifas. Yogyakarta: ANDI

Wiji, R.N. 2013.ASI Panduan Ibu Menyusui. Yogyakarta: Nuha Medika 